\title{
Terapeutyczna plazmafereza w praktyce klinicznej
}

\section{Therapeutic plasmapheresis in clinical practice}

\author{
Beata Wiśniewska \\ Pracownia Transfuzjologii Klinicznej z Bankiem Krwi, Zakład Transfuzjologii, \\ Instytut Hematologii i Transfuzjologii, Warszawa
}

\begin{abstract}
Streszczenie
Plazmafereza lecznicza jest zabiegiem, który wykonany z wtaściwych wskazań wplywa na poprawe stanu klinicznego pacjenta $i$ jego rokowania, a także jest jedna $z$ metod leczenia ostrej fazy schorzeń o podtożu immunizacyjnym. W niniejszym artykule przedstawiono teoretyczne $i$ praktyczne możliwości wykorzystania plazmaferezy leczniczej oraz jej zastosowanie jako metody pomocniczej wspomagajacej leczenie $w$ różnych jednostkach chorobowych w oparciu o zabiegi wykonane w Zaktadzie Transfuzjologii Klinicznej Instytutu Hematologii $i$ Transfuzjologii w latach 2016-2017. Opisano mechanizm dziatania plazmaferezy, wykorzystywane metody oraz jej wplyw na niektóre sktadniki krwi i osocza. W artykule przedstawiono bardzo istotna role pielegniarki uczestniczacej $w$ procesie plazmaferezy, $w$ szczególności w odniesieniu do mogacych wystapić powiktań zwiazanych $z$ samym zabiegiem.
\end{abstract}

Słowa kluczowe: hemafereza lecznicza, plazmafereza, separator

Hematologia 2018; 9, 4: 306-317

\begin{abstract}
Plasmapheresis is a procedure which performed for appropriate indications contributes to the improvement of patients' clinical condition and treatment prognosis. Plasmapheresis is also one of the therapy methods used in acute phases of autoimmune disorders. Hereby, the theoretical and practical possibilities offered by therapeutic plasma exchange in supportive treatment of various medical conditions are described. The article is based on the reports of procedures performed at the Department of Transfusion Medicine of the Institute of Hematology and Transfusion Medicine in the period 2016-2017. It presents the mechanism of plasmapheresis, the methods used in everyday practice as well as the effect of the procedure on blood components and plasma. It also emphasizes the significant role of the nurse in the plasmapheresis procedure particularly in relation to possible complications and adverse reactions.
\end{abstract}

Key words: therapeutic hemapheresis, plasmapheresis, cell separator

Hematologia 2018; 9, 4: 306-317

\section{Wprowadzenie}

Plazmafereza to zabieg polegający na pobraniu określonej objętości krwi oraz szybkim jej rozdzieleniu na osocze i elementy komór- kowe, które następnie zostają zwrócone drogą reinfuzji. Wyróżnia się plazmaferezę leczniczą, określaną mianem terapeutycznej wymiany osocza (TPE, therapeutic plasma exchange), oraz preparatywną [1].

Adres do korespondencji: Beata Wiśniewska, Zakład Transfuzjologii Klinicznej, Instytut Hematologii i Transfuzjologii, ul. Indiry Gandhi 14, 02-776 Warszawa, tel. 223496 569, e-mail: axa-2007@o2.pl 
Można stwierdzić, że plazmafereza jest metodą nieswoistej wymiany osocza łączącą w sobie elementy transfuzji autologicznej i hemodylucji normowolemicznej. To jedna $z$ technik pozaustrojowego oczyszczania krwi pacjenta $z$ endo- i egzogennych toksyn. Etymologia pojęcia plazmaferezy wywodzi się $z$ greckich słów 'plasma' (osocze) oraz 'apheresis' (proces usuwania). Pierwsze wzorce takiego postępowania pochodzą $z$ lat 1902 i 1906, w których Hedon i Morawitz przeprowadzili tego typu zabiegi u królików i psów. Wykonawcą pierwszej doświadczalnej plazmaferezy był John Abel, który w 1914 roku zastosował tę metodę do skutecznego usunięcia toksyn $z$ organizmu. Zapoczątkowane przez Cohna w 1944 roku frakcjonowanie osocza umożliwiło wprowadzenie do lecznictwa wielu preparatów osoczopodobnych dzięki wykorzystaniu plazmaferezy, tj. pobrania krwi pełnej, szybkiego odwirowania osocza i reinfuzji krwinek dawcy [1]. W tym samym roku zastosowano pierwsze zabiegi plazmaferezy, które początkowo wykorzystywano do pozyskiwania osocza od dawców krwi, a następnie również do celów terapeutycznych. Pierwsze zabiegi plazmaferezy wykonywano metodą manualną, obecnie natomiast przeważają techniki zautomatyzowane wykorzystujące w tym celu separatory komórkowe, które umożliwiają szybkie i skuteczne przeprowadzenie zabiegu.

\section{Mechanizm plazmaferezy}

Zgodnie $z$ definicją mechanizm plazmaferezy polega na pozaustrojowym oddzieleniu osocza wraz $z$ ewentualnymi jego patologicznymi składnikami odpowiedzialnymi za wywołanie i podtrzymanie procesu chorobowego (m.in. autoprzeciwciała, immunoglobuliny, cytokiny) od elementów morfotycznych krwi. Niezbędnym warunkiem przeprowadzenia tej procedury, pozwalającym na uniknięcie procesów aktywacji krzepnięcia w obrębie krążenia pozaustrojowego i powikłań zakrzepowo-zatorowych, jest antykoagulacja. Pozaustrojowy przepływ krwi odbywa się w jednorazowym, jałowym zestawie separacyjnym. Krew pacjenta, pobierana przez separator, miesza się $z$ roztworem antykoagulantu (heparyna, roztwory cytrynianu) i napływa do naczynia wirówkowego lub filtra, gdzie następuje rozdzielenie osocza od elementów komórkowych krwi. Objętość oddzielonego osocza zostaje zastąpiona przez płyny zastępcze, a odzyskiwane erytrocyty, płytki krwi (PLT, platalets) i leukocyty są bezpośrednio lub pośrednio zwrotnie przetaczane pacjentowi. Najczęściej stosowane płyny zastępcze to koloidy (5-proc. albuminy) i krystaloidy.
Świeżo mrożone osocze (FFP, fresh frozen plasma) inaktywowane lub osocze pozbawione czynnika VIII stosuje się rzadko ze względu na ryzyko wystąpienia powikłań w postaci reakcji nadwrażliwości. Natomiast powszechnie wykorzystywane są krystaloidy ze względu na ich dostępność, brak reakcji niepożądanych i niską cenę. Co więcej, nie zakłócają one hemostazy i zwiększają diurezę. Ich wadą jest jednak krótkotrwałe utrzymywanie się w krążeniu [2].

W wyniku zastosowania plazmaferezy uzyskuje się mechaniczne oczyszczenie krwi pacjenta z patologicznych składników osocza. Ilość usuwanego osocza powinna być odnoszona do całkowitej objętości osocza we krwi własnej pacjenta. Objętość wymiany zależy od stanu klinicznego pacjenta oraz od całkowitej objętości osocza w organizmie.

Wydajność eliminacji poszczególnych substancji jest uzależniona od ich indywidualnych właściwości oraz od ich rozmieszczenia w przestrzeniach wewnątrz- i zewnątrznaczyniowej. $Z$ dużą skutecznością są usuwane immunoglobuliny $\mathrm{M}$ i fibrynogen znajdujące się przede wszystkim $\mathrm{w}$ przestrzeni wewnątrznaczyniowej. Mniejsza jest natomiast wydajność eliminacji immunoglobuliny G, rozmieszczonej równomiernie $\mathrm{w}$ przestrzeniach wewnątrz- i zewnątrznaczyniowej, jednak obniżenie stężenia IgG można uzyskać, powtarzając zabiegi. Szacuje się, że aby usunąć średnio $75 \%$ szkodliwych substancji, powinno się jednorazowo wymienić około 1,5 całkowitej objętości osocza, czyli 2500-3500 ml. Wartość ta nie powinna być jednak jednorazowo mniejsza niż całkowita objętość osocza chorego. Wymiana większych objętości rzadko bywa uzasadniona ze względu na postępujące zmniejszenie wydajności zabiegu. Po zabiegu stężenie ponownie wzrasta na skutek ponownej syntezy szkodliwych substancji, jak również ich przechodzenia $z$ przestrzeni zewnątrznaczyniowej do wewnątrznaczyniowej i powrocie wraz $z$ chłonką. $Z$ tego względu zabieg plazmaferezy powinien być powtarzany (zwykle co $24-48 \mathrm{~h}$ ). Zazwyczaj wykonuje się 4-5 kolejnych zabiegów, co skutkuje obniżeniem stężenia szkodliwego czynnika o około 90\% w stosunku do stężenia wyjściowego. Odsetek usuwanych cząsteczek zależy od ich wielkości, okresu póltrwania w osoczu oraz tempa syntezy [2].

Zastosowanie techniki pozaustrojowego oczyszczania krwi może stanowić doraźną pomoc dla chorego (np. w przypadkach zatrucia czy zespole nadlepkości w przebiegu szpiczaka plazmocytowego [PCM, plasma cell myeloma]). Do niedawna plazmaferezę stosowano w ostateczności, w stanach zagrożenia życia. Stosuje się ją również w celu 
wspomagania klasycznych metod leczenia szeroko pojętej niewydolności narządów wewnętrznych. Usunięcie cytokin, immunoglobulin, prostanoidów pobudza organizm do ich wzmożonej, jakościowo zmienionej syntezy, ujawniając immunomodulacyjny efekt plazmaferezy [3, 4]. Intensywność zabiegów określa się przeważnie empirycznie, ponieważ optymalnych schematów stosowania aferez nie ustalono w odniesieniu do większości jednostek chorobowych w ramach randomizowanych badań klinicznych.

\section{Rodzaje plazmaferezy}

Obecny stan wiedzy dotyczący rozdziału krwi na składniki umożliwia wykonanie plazmaferezy $z$ wykorzystaniem różnicy ich ciężarów właściwych (sedymentacja, wirowanie), różnicy wielkości składników komórkowych (filtracja przez błonę membranową - plazmafiltracja) oraz zjawiska immunoadsorbcji (plazmaperfuzja) [3, 5].

Klasycznym sposobem wymiany osocza jest metoda sedymentacyjno-wirownicza, polegająca na oddzieleniu osocza od elementów morfotycznych krwi za pomocą różnych szybkości sedymentacji w polu siłowym wirówki. W przypadku braku odpowiednich aparatów do całkowitej wymiany osocza można stosować metodę manualną. Jest to zabieg plazmaferezy frakcjonowanej $\mathrm{w}$ połączeniu $z$ hemodylucją - sposobem upustu krwi oraz odwirowaniem pobranej krwi w chłodzonych wirówkach, $z$ wykorzystaniem odpowiednich parametrów wirowania. Metody manualne wymagają oddzielenia składników komórkowych, wyodrębnionych $\mathrm{w}$ procesie wirowania, przy użyciu prasy mechanicznej lub automatycznej. Obie te metody można dodatkowo uzupełniać, stosując płukanie krwinek czerwonych oraz zawieszając je w odpowiednim dla sytuacji klinicznej roztworze (5-proc. albuminy, 0,9-proc. $\mathrm{NaCl})$. Cechuje je także możliwość mechanicznego uszkodzenia krwinek i znacznej hemolizy lub zakażenia przetaczanej masy erytrocytarnej, co może się przyczynić do groźnych powikłań $[5,6]$.

Metoda filtracyjna (separacja przezbłonowa) polega na przepływie krwi przez specjalne filtry kapilarno-membranowe (o określonej wielkości porów), co umożliwia oddzielenie elementów morfotycznych od osocza, które zostaje usunięte $z$ odfiltrowanymi cząsteczkami i substancjami. Właściwości filtracyjne zależą od rodzaju tworzywa, powierzchni mikrokapilar, ich wielkości oraz od szybkości przepływu krwi. Użycie filtrów może powodować aktywację układu dopełniacza C3 oraz indukować reakcje anafilaktyczne [5].
Metoda plazmaperfuzji polega na filtracji $z$ wykorzystaniem immunoadsorbentów, w skład których wchodzą nośnik obojętny chemicznie oraz antygen wykazujący szczególne powinowactwo do konkretnej klasy przeciwcial [5].

Oczyszczanie osocza może się odbywać w sposób przerywany lub ciągły. Sposób przerywany (metoda wymaga jednoświatłowego cewnika naczyniowego) polega na rozdzieleniu krwi na osocze i elementy morfotyczne, a następnie na oczyszczeniu lub usunięciu osocza i ponownym przetoczeniu substancji morfotyczych do organizmu chorego w stosownej objętości płynów zastępczych (np. płyny elektrolitowe, FFP, albuminy). Ograniczeniem tej metody jest dość znaczne - przejściowe - zmniejszenie objętości krwi w w organizmie chorego. Sposób ciągły polega na jednoczasowym pobieraniu, oczyszczaniu i zwrotnym przetaczaniu krwi [6].

\section{Dostęp naczyniowy}

Plazmafereza wymaga odpowiedniego dostępu naczyniowego będącego jednym $z$ warunków skutecznie i efektywnie wykonanej plazmaferezy leczniczej. Dopuszczalne są połączenia sposobem tętniczo-żylnym lub żylno-żylnym [2]. W celu uniknięcia ryzyka wystąpienia hemolizy zaleca się stosowanie igieł o rozmiarze 1,6-2 mm zakładanych do dużych żył zgięcia łokciowego. U pacjentów, u których dostęp naczyniowy jest utrudniony, stosuje się standardowy cewnik dwukanałowy 2 razy 14 G, wprowadzony do żyły głównej górnej przez żyłę szyjną wewnętrzną lub żyłę podobojczykową, zdecydowanie rzadziej przez żyłę udową, co umożliwia jednoczasowe pobieranie i oddawanie krwi oraz płynów do układu krążenia chorego. Niezależnie od rodzaju zastosowanego separatora konieczna jest skuteczna antykoagulacja $z$ użyciem heparyny bądź cytrynianu (zgodnie $z$ zaleceniami producentów separatorów komórkowych). W chorobach przebiegających $\mathrm{z}$ zaburzeniami krzepnięcia, takich jak zakrzepowa plamica małopłytkowa (TTP, thrombotic thrombocytopenic purpura), preferuje się zastosowanie cytrynianu. Zasada antykoagulacji przy użyciu cytrynianu polega na wiązaniu jonów wapnia, które są niezbędnym składnikiem kaskady krzepnięcia. Stosowane antykoagulanty to 4-procentowy roztwór cytrynianu sodowego oraz ACD-A (acid citric [kwas cytrynowy], citrate, dextrose [glukoza]), w skład którego wchodzą: 22,0 g/l cytrynianu trójsodowego, 8,0 g/l kwasu cytrynowego i $24,5 \mathrm{~g} / \mathrm{l}$ glukozy. Zaleca się stosowanie antykoagulantu wskazanego przez producenta 
separatora komórkowego, gdyż nawet niewielkie odchylenia od prawidłowego składu mogą prowadzić do groźnych powikłań u chorego. U zdrowego człowieka kwas cytrynowy ulega szybkim przemianom, a końcowymi produktami jego rozpadu są dwutlenek węgla i dwuwęglan sodu wydalany z moczem. Utlenianie cytrynianu przebiega szybko we wszystkich tkankach, a przede wszystkim w wątrobie. W ciągu 20-30 s rozkłada się $60-70 \%$ podanego cytrynianu, natomiast w ciągu $5-10 \mathrm{mi}-$ nut - około $90 \%$. U chorych $\mathrm{z}$ zaburzeniami gospodarki kwasowo-zasadowej (np. w chorobach wątroby czy nerek) ryzyko wystąpienia stanu nadwrażliwości na cytrynian oraz jego znacznej kumulacji jest wyższe. W stanach hipotermii obserwuje się obniżoną tolerancję na przetoczony cytrynian. W takich przypadkach sposób dawkowania i monitorowania podawanego w trakcie zabiegu antykoagulantu powinien ustalić lekarz.

\section{Teoretyczne i praktyczne możliwości terapeutycznego wykorzystania plazmaferezy}

Plazmafereza znalazła zastosowanie w leczeniu chorób i zaburzeń związanych $z$ występowaniem nieprawidłowych białek lub toksyn i może przyjmować jedną $z$ trzech form:

- całkowitej wymiany osocza;

- frakcjonowania osocza;

- poddania sorpcji.

Dwie ostatnie metody umożliwiają wyodrębnienie endotoksyn i usunięcie ich $z$ osocza pacjenta [7]. Plazmaferezę stosuje się w leczeniu chorób związanych:

- $\quad$ z nadmiernym stężeniem specyficznych białek (np. białka monoklonalnego makroglobulin $\mathrm{w}$ makroglobulinemii Waldenströma [WM, Waldenström macroglobulinemia] i w PCM);

- $\quad$ z nadmierną ilością związanych $z$ białkiem substancji (np. toksyn w chorobach wątroby, hormonów tarczycy w nadczynności tarczycy, lipoprotein w hipercholesterolemii);

- $\quad z$ wytwarzaniem przeciwcial przeciw własnym antygenom (np. miastenia, zapalenie kłębuszkowe nerek);

- $\quad$ z odkładaniem się w tkankach kompleksów immunologicznych (np. reumatoidalne zapalenie stawów, toczeń rumieniowaty układowy);

- $\quad z$ patogenami lub ich fragmentami, toksynami, nieprawidłowymi metabolitami produkowanymi $\mathrm{w}$ odpowiedzi na zakażenie lub zarażenie — do tej kategorii schorzeń zalicza się choroby pasożytnicze (zimnica, włośnica, trypanoso- moza) oraz choroby bakteryjne (wstrząs septyczny, borelioza - postać mózgowa).

Plazmafereza przyczynia się do cofania zespołu wątrobowo-nerkowego $u$ chorych $z$ ciężkim wirusowym zapaleniem wątroby oraz poprawia metabolizm komórek nerwowych i hepatocytów. U chorych zakażonych ludzkim wirusem niedoboru odporności (HIV, human immunodeficiency virus) $z$ kolei procedura ta wplywa na zahamowanie spadku odsetka limfocytów CD4. Jest także skuteczna $\mathrm{w}$ leczeniu neuropatii. U pacjentów z posocznicą zabieg plazmaferezy powoduje usuwanie mediatorów wstrząsu septycznego, przeciwdziałając ich hamującemu wpływowi na układ immunologiczny [6].

Zabiegi plazmaferezy stosowane w polineuropatiach, zespole Guillaina-Barrégo (GBS, Guillain-Barré syndrome) oraz $\mathrm{w}$ miastenii wykonuje się $\mathrm{w}$ celu usunięcia autoprzeciwciał skierowanych przeciw komponentom nerwów obwodowych lub ośrodkowych. Prowadzi to do zatrzymania procesów demielinizacyjnych i wpływa bezpośrednio na supresję immunologiczną [7].

W chorobach krwi plazmaferezę stosuje się $\mathrm{w}$ celu usunięcia autoprzeciwciał oraz modyfikacji odpowiedzi immunologicznej. Wykorzystuje się ją w leczeniu:

- PCM - obniża stężenie białka monoklonalnego;

- $\mathrm{WM}$ - powoduje zmniejszenie miana immunoglobuliny klasy IgM;

- choroby Willenbranda - hamuje postępującą małopłytkowość i obniżenie stężenia czynnika VIII;

- nabytego zespołu zmniejszenia aktywności czynnika VIII - umożliwia usunięcie $z$ krążenia autoprzeciwciał skierowanych przeciw temu czynnikowi [7];

- chorób przebiegających z małopłytkowością, w których obserwuje się cechy mikroangiopatii. W takich przypadkach zabieg plazmaferezy zapobiega mikroangiopatiom narządowym głównie w ośrodkowym układzie nerwowym i w nerkach. Umożliwia usunięcie $z$ krwi multimerów przyczyniających się do agregacji płytek krwi;

- w chorobach tkanki łącznej (toczeń trzewny, sklerodermia, reumatoidalne zapalenie stawów) - umożliwia usunięcie różnego rodzaju autoprzeciwciał obecnych w surowicy.

W literaturze opisano również zastosowanie plazmaferezy w leczeniu hipercholesterolemii lekoopornej oraz w toksykologii; umożliwia na przykład udzielenie natychmiastowej pomocy w przypadku zatruć grzybami, przy czym największą 
skuteczność zabiegu odnotowuje się w ciągu pierwszych $24 \mathrm{~h}$ od spożycia trujących grzybów [8, 9].

Techniki membranowe wykorzystane przy frakcjonowaniu osocza są teoretycznie najprostsze w użyciu i najtańsze, jednak charakteryzują się niepożądaną znaczną utratą białek i często zbyt małą selektywnością. Najlepszy efekt terapeutyczny, służący selektywnemu usunięciu $z$ krwi chorego chorobotwórczych autoprzeciwciał, uzyskuje się, wykorzystując immunoadsorbenty w krążeniu pozaustrojowym. Ze względu na bardzo wysokie koszty produkcji przeciwciał są one wielokrotnie stosowane $\mathrm{u}$ tego samego chorego. Koszty eksploatacji dodatkowo zwiększa konieczność przechowywania kolumn w sterylnych warunkach $\left(4^{\circ} \mathrm{C}\right.$, dodatek $\left.\mathrm{NaN}_{3}\right)$, w przeciwnym razie wzrasta niebezpieczeństwo zakażeń (wielokrotne stosowanie kolumn) oraz immunizacji pacjenta (wyciekanie przeciwcial). Do najbardziej skomplikowanych i kosztownych procedur należą metody lączące w sobie techniki membranowe i sorbcyjne (np. system HELP do usuwania cholesterolu frakcji lipoprotein o dużej gęstości [LDL, low-density lipoprotein]). Trwają poszukiwania nowych materiałów i technik charakteryzujących się niską ceną produkcji i umożliwiających eksploatację na masową skalę [7].

\section{Wskazania do leczenia zabiegami plazmaferezy (klasyfikacja chorób)}

Według najszerzej stosowanych wytycznych ASFA (American Society of Apheresis) występują cztery kategorie wskazań do leczenia plazmaferezą [10]:

- kategoria I - afereza jako terapia pierwszego rzutu, stosowana samodzielnie lub w połączeniu $z$ innymi metodami leczenia;

- $\quad$ kategoria II - afereza jako terapia drugiego rzutu, stosowana samodzielnie lub w połączeniu $z$ innymi metodami leczenia;

- $\quad$ kategoria III - optymalne zastosowania aferezy nieustalone, decyzje należy podejmować indywidualnie;

- kategoria IV - opublikowano dowody braku skuteczności lub szkodliwości aferezy.

Dodatkowo zastosowano klasyfikację siły zaleceń ASFA według systemu GRADE (Grades of Recommendation, Assessment, Development, and Evaluation) do oceny jakości danych i określania siły zaleceń w praktyce klinicznej, co umożliwiło bardziej precyzyjną ocenę przydatności aferezy [11]. Rekomendacje dotyczą wskazań, techniki aferezy oraz schematu leczenia w różnych stanach chorobowych i zostały opracowane przez grupy eksperckie $z$ prestiżowych towarzystw naukowych na podstawie obecnego stanu wiedzy medycznej, ze szczególnym uwzględnieniem wyników randomizowanych kontrolowanych badań klinicznych [10].

Zgodnie $z$ aktualnymi zaleceniami ASFA każdy zabieg aferezy stanowi leczenie pierwszego rzutu w ponad 50 schorzeniach. W kolejnych kilkudziesięciu stanach klinicznych zabieg aferezy jest leczeniem drugiego rzutu, jeśli terapia uznawana za podstawową okaże się nieskuteczna [10]. Należy jednak pamiętać, że kryteria wykonania zabiegu według ASFA nie w każdym przypadku są zgodne $z$ wytycznymi innych organizacji eksperckich. W ostatnich latach lista wskazań do stosowania TPE stopniowo się wydłużała, jednak w randomizowanych badaniach kontrolowanych wykazano jej skuteczność kliniczną tylko w ograniczonej liczbie chorób.

Plazmafereza jest akceptowaną, ale nieobowiązującą metodą leczenia:

- w zespole nadmiernej lepkości krwi - obecność patologicznych immunoglobulin;

- w przełomie miastenicznym - przeciwciała przeciw antygenom receptora acetylocholiny, krioglobuliny;

- w zespole Goodpasture'a bez niewydolności nerek - przeciwciała przeciw antygenom błony podstawnej kłębuszków;

- w kłębuszkowych zapaleniach nerek z niewydolnością — kompleksy immunologiczne;

- w przełomie tarczycowym;

- w zatruciu (toksynami wiążącymi się z białkiem);

- w rodzinnej hipercholesterolemii - cholesterol, lipoproteidy.

W przypadkach opornych na leczenie plazmaferezę stosuje się:

- $\quad$ w GBS - przeciwciała przeciw antygenom mieliny;

- w autoimmunologicznym zapaleniu mózgu - przeciwciała antyneuronalne CASPR oraz NMDA;

- w postępującym toczniu rumieniowatym układowym - przeciwciała przeciw DNA;

- $\quad \mathrm{w}$ hemofilii z obecnością krążącego antykoagulantu;

- $\quad$ w przypadku odrzucenia przeszczepu nerki - kompleksy immunologiczne, przeciwciała przeciw antygenom ludzkich antygenów leukocytarnych (HLA, human leukocyte antigens);

- w postępującym zapaleniu naczyń z obecnością kompleksów immunologicznych.

Użyteczność plazmaferezy pozostaje nieudowodniona lub niewystarczająco zbadana: 
- w reumatoidalnym zapaleniu stawów - czynnik reumatoidalny (makroglobulina S19), krioglobuliny, immunoglobuliny anty-IgG, anty-IgM;

- w stwardnieniu rozsianym - przeciwciała przeciw antygenom mieliny;

- w przypadku konfliktu matczyno-płodowego przeciwciała przeciw antygenom $\mathrm{Rh}$;

- w plamicy małopłytkowej na tle immunizacyjnym;

- w rozsianym procesie nowotworowym - przeciwciała specyficzne dla nowotworu, kompleksy immunologiczne $[6,12,13]$.

\section{Powikłania podczas zabiegu aferezy}

Powikłania podczas zabiegu TPE zdarzają się stosunkowo rzadko (4-5\%) i zazwyczaj są to reakcje łatwo odwracalne, takie jak na przykład: mrowienie/drętwienie (parestezje) i skurcze mięśni kończyn (spowodowane obniżeniem stężenia jonów wapnia), pokrzywka, zawroty głowy, nudności, wymioty, hipotonia. Powikłania zagrażające życiu stanowią jedynie $0,025-0,2 \%$ i często są związane nie $z$ procedurą jako taką, ale ze skrajnie ciężkim stanem chorego przed zabiegiem. Powikłania podczas TPE dotyczą najczęściej cewnikowania żył centralnych, przetaczania preparatów krwiopochodnych i innych płynów substytucyjnych, antykoagulacji oraz samej techniki zabiegu i zależą od doświadczenia pielęgniarek przeprowadzających zabieg. Jednym $z$ częstszych powikłań podczas zabiegu jest obniżenie stężenia jonów wapnia we krwi chorego. Hipokalcemia powoduje zaburzenie progu pobudliwości struktur nerwowo-mięśniowych, co może skutkować pojawieniem się objawów tężyczki lub jej równoważników [14]. Mogą wystąpić parestezje kończyn, wzmożenie odruchów ścięgnistych, napady drgawek, obniżenie ciśnienia tętniczego, zmniejszenie rzutu serca, jak również komorowe zaburzenia rytmu serca. Hipokalcemia jest wynikiem stosowania cytrynianu sodu (przy produkcji FFP) - antykoagulantu wiążącego jony wapnia, dlatego podczas zabiegu powinno się zapobiegawczo stosować suplementację jonów wapnia pod postacią glukonianu. Życiu pacjenta mogą zagrażać powikłania pod postacią obniżenia rzutu serca i hipotonii, reakcji anafilaktycznej lub sepsy. Reakcje alergiczne i anafilaktyczne są głównie związane $z$ przetaczaniem FFP i w zdecydowanej większości przypadków dotyczą chorych $z$ TTP leczonych zabiegami plazmaferezy. Objawiają się one pokrzywką, świądem skóry, podwyższoną ciepłotą ciała, a w skrajnych przypadkach mogą przebiegać pod postacią wstrząsu anafilaktycznego. Częstość występowania reakcji anafilaktycznych zdecydowanie maleje, jeśli płynami zastępczymi są roztwory albuminy. Reakcje anafilaktoidalne o mniejszym nasileniu mogą się pojawić w odpowiedzi na zetknięcie się krwi chorego $z$ filtrem i układem drenów sterylizowanym tlenkiem etylenu. Częstość występowania takich reakcji można ograniczyć poprzez odpowiednie płukanie plazmafiltra przy użyciu 0,9-procentowego $\mathrm{NaCl}[6]$.

Powikłania w postaci skazy krwotocznej oraz stanów nadkrzepliwości wynikają z zaburzeń w układzie krzepnięcia i są następstwem utraty czynników krzepnięcia w trakcie TPE. W przypadku całkowitej wymiany osocza po jednorazowym zabiegu stężenie osoczowych czynników krzepnięcia (czynniki V, VII, IX, X, fibrynogen) obniża się w przybliżeniu o 60\%. Powikłania krwotoczne mogą być również skutkiem stosowanej antykoagulacji (heparyna, cytrynian) i manifestują się krwawieniem w miejscu założenia cewnika do żyły, krwawieniem $z$ błon śluzowych nosa, wymiotami krwistą treścią lub też odkrztuszaniem krwistej wydzieliny $z$ oskrzeli. Przejściowe obniżenie wartości antytrombiny podczas zabiegu może predysponować do wystąpienia żylnej choroby zakrzepowo-zatorowej [1]. W schemacie codziennych zabiegów wymiany osocza wzrasta podatność na zakażenia spowodowana obniżeniem miana immunoglobulin oraz stężeń składowych dopełniacza C3 i C4.

Komplikacje związane z założeniem cewnika do żyły centralnej należą do typowych dla tej procedury i obejmują: odmę opłucnową, zator powietrzny, krwiak w miejscu wkłucia, zakażenie, zakrzepicę żylną. Jeśli zabieg terapeutycznej plazmaferezy jest przeprowadzony według opracowanych standardów przez przeszkolony i doświadczony zespół pielęgniarek, to ryzyko wystąpienia niepożądanych objawów niepożądanych (patrz tab. 1) pozostaje niewielkie.

Zastosowanie separatora jako jednej $z$ metod postępowania leczniczego w niektórych jednostkach chorobowych lub wykonanie plazmaferezy metodą manualną odbywa się tylko na podstawie decyzji lekarza specjalisty, który stwierdzi konieczność przeprowadzenia takiego zabiegu $z$ myślą o dalszym przebiegu leczenia pacjenta. Na podstawie stanu klinicznego chorego lekarz ustala rodzaj i ilość płynów stosowanych w celu wyrównania objętości krwi krążącej oraz ilość wymienionego osocza. 
Tabela 1. Działania niepożądane związane z plazmaferezą

Table 1. Adverse events associated with plasmapheresis

\begin{tabular}{|c|c|c|}
\hline Rodzaj suplementacji & Powikłania & Objawy \\
\hline \multirow[t]{6}{*}{$\begin{array}{l}\text { FFP } \\
\text { FFP bez AHG } \\
\text { FFP inaktywowane }\end{array}$} & $\begin{array}{l}\text { Niehemolityczne reakcje poprzetoczeniowe } \\
\text { Wstrząs }\end{array}$ & $\begin{array}{l}\text { Gorączka } \\
\text { Dreszcze } \\
\text { Hipotensja } \\
\text { Pokrzywka } \\
\text { Skurcz oskrzeli } \\
\text { Niewydolność oddechowa } \\
\text { Niepokój }\end{array}$ \\
\hline & Pokrzywka & $\begin{array}{l}\text { Świąd } \\
\text { Typowe zmiany skórne }\end{array}$ \\
\hline & Przeniesienie zakażenia & HBV, HCV, HIV \\
\hline & Posocznica & $\begin{array}{l}\text { Gorączka } \\
\text { Dreszcze } \\
\text { Wstrząs septyczny }\end{array}$ \\
\hline & Zatrucie cytrynianem & $\begin{array}{l}\text { Zasadowica metaboliczna } \\
\text { Hipokalcemia }\end{array}$ \\
\hline & TRALI & $\begin{array}{l}\text { Hipoksemia } \\
\text { Hipotensja } \\
\text { Gorączka }\end{array}$ \\
\hline 20-proc. albuminy & $\begin{array}{l}\text { Ostra hiperwolemia } \\
\text { Obrzęk płuc }\end{array}$ & $\begin{array}{l}\text { Hipertonia } \\
\text { Duszność } \\
\text { Kaszel } \\
\text { Sinica } \\
\text { Tachykardia } \\
\text { Niewydolność oddechowa obrzęki }\end{array}$ \\
\hline
\end{tabular}

FFP (fresh frozen plasma) inaktywowane - świeżo mrożone osocze po redukcji biologicznych czynników chorobotwórczych; AHG (anti-hemophylic globulin) — globulina antyhemofilowa; HBV (hepatitis B virus) — wirus zapalenia wątroby typu B; HCV (hepatitis C virus) - wirus zapalenia wątroby typu C; HIV (human immunodeficiency virus) - ludzki wirus niedoboru odporności; TRALI (transfusion-related acute lung injury) - ostre potransfuzyjne uszkodzenie płuc

\section{Wykorzystanie plazmaferezy leczniczej na podstawie zabiegów wykonanych w Zakładzie Transfuzjologii Instytutu Hematologii i Transfuzjologii (IHT) w latach 2016-2017}

W Zakładzie Transfuzjologii IHT zabiegi plazmaferezy wykonuje się obecnie przy użyciu separatora komórkowego typu Spectra Optia (Terumo-BCT, Tokio, Japonia) wykorzystującego metodę wirowniczą o przepływie ciągłym, $z$ dostępem naczyniowym żylno-żylnym, $z$ zastosowaniem antykoagulantu ACD formuła A. Na rycinie 1 przedstawiono wzrost liczby wykonywanych zabiegów plazmaferezy w ostatnich 4 latach.

W latach 2016-2017 zabiegom plazmaferezy poddano łącznie 34 pacjentów w wieku 24-72 lat (średnia 48 lat), w tym 14 kobiet i 20 mężczyzn, u których przeprowadzono łącznie 370 zabiegów. Liczba wykonanych procedur zależała od stanu klinicznego pacjenta oraz rodzaju choroby. Niezależnie od terapeutycznej wymiany osocza we wszystkich schorzeniach stosowano leczenie uzupełniające zgodnie $z$ zaleceniami klinicznymi obowiązującymi w tych jednostkach chorobowych. $\mathrm{W}$ tabeli 2 przedstawiono jednostki chorobowe, w których wdrożono leczenie zabiegami plazmaferezy, wraz klasyfikacją według ASFA $[10,15]$.

Przed przystąpieniem do zabiegu terapeutycznej wymiany osocza u każdego pacjenta wykonuje się następujące badania krwi: morfologię $z$ oceną liczby PLT, proteinogram, pomiar stężeń jonów wapnia, magnezu, sodu i potasu w surowicy oraz pierwszorazowo oznaczenie grupy krwi w układach AB0 i Rh (dotyczy szczególnie plazmaferez wykonywanych metodą manualną oraz chorych, u których jest wymagana suplementacja FFP). Zastosowane parametry w wybranych jednostkach chorobowych podano w tabeli 3.

Największą liczbę zabiegów wykonano u 9 pacjentów $z$ niedoborem osoczowej metaloproteinazy ADAMTS13 (a disintegrin and metalloprotease with thrombospondin type 1 motifs 13 [13 przedstawiciel rodziny dezintegryn i metaloproteinaz $\mathrm{z}$ motywem trombospondyny typu 1]) i $z$ inhibitorem przeciw ADAMTS13; średnio 3-50 zabiegów u jednego chorego (łącznie wykonano 278 zabiegów). W większości przypadków zabiegi przeprowadzano codziennie 


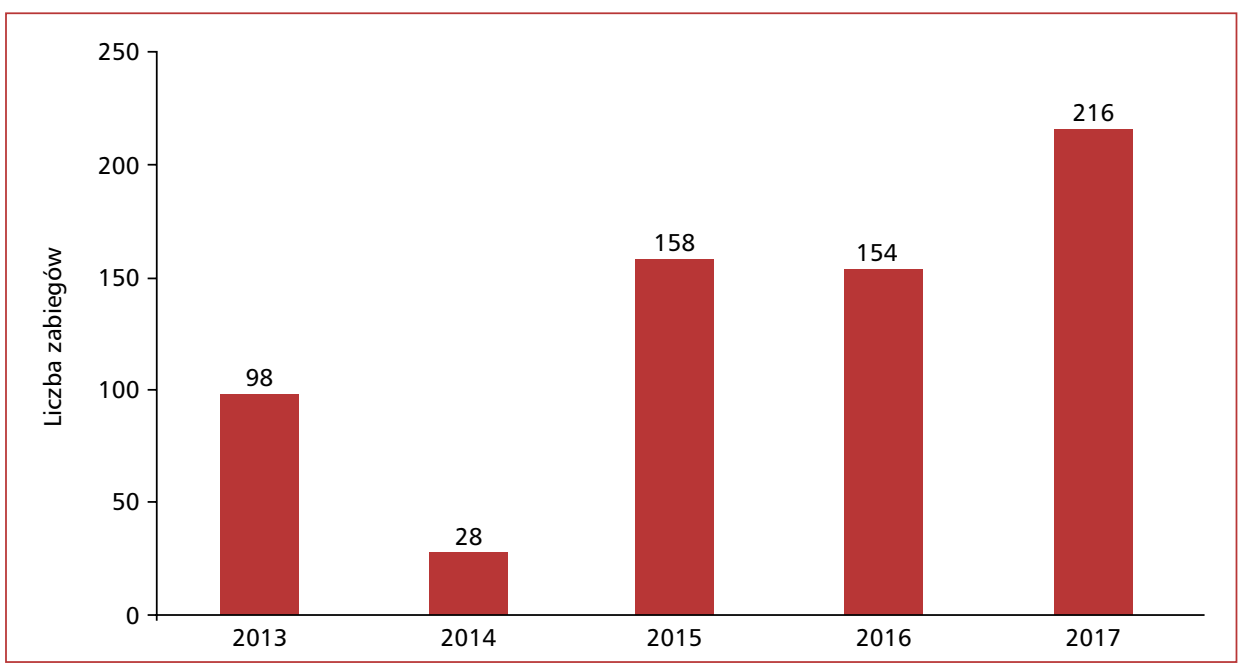

Rycina 1. Liczba wykonanych zabiegów plazmaferezy (2013-2017)

Figure 1. Number of plasmapheresis procedures (2013-2017)

Tabela 2. Jednostki chorobowe, w których zastosowano leczenie zabiegami plazmaferezy (kategoria; siła dowodu — American Society of Apheresis [ASFA] 2016)

Table 2. Therapeutical plasmapheresis used in the treatment of diseases (category; grade of recommendation; American Society of Apheresis [ASFA] 2016)

\begin{tabular}{|l|c|c|c|c|}
\hline \multirow{2}{*}{ Jednostka chorobowa } & \multicolumn{2}{|c|}{ ASFA 2016 } & \multicolumn{2}{c|}{ Liczba zabiegów } \\
\cline { 2 - 5 } & Kategoria & Siła dowodu & 2016 & 2017 \\
\hline Zakrzepowa plamica małopłytkowa & I & 1A & 117 & 161 \\
\hline Szpiczak plazmocytowy & I & 1B & 6 & 21 \\
\hline Toksyczna nekroliza naskórka (zespół Lyella) & III & 2B & 19 & 0 \\
\hline Zespół hemolityczno-mocznicowy & III & 2C & 5 & 0 \\
\hline Autoimmunologiczne zapalenie mózgu & I & 1B & 5 & 21 \\
\hline Zespół paranowotworowy & III & 2C & 2 & 0 \\
\hline Ziarniniakowatość z zapaleniem naczyń ANCA+ & I & 1A & 0 & 8 \\
\hline Przeciwciała klasy lgG/lgA (polineuropatia demielizacyjna) & I & 1B & 0 & 5 \\
\hline Łącznie & & & 154 & 216 \\
\hline
\end{tabular}

ANCA (anti-neutrophil cytoplasmic antibody) - przeciwciała przeciw cytoplazmie neutrofilów

Z wyjątkiem pacjentów $z$ oporną postacią choroby, u których zabiegi wykonywano 2 razy/dobę, wymieniając łącznie 2-3 objętości osocza pacjenta. Po uzyskaniu poprawy klinicznej i stabilizacji stanu pacjenta wykonywano plazmaferezę raz na dobę, wymieniając tylko jedną objętość osocza. Zalecono kontynuację plazmaferez co najmniej przez 2 dni po uzyskaniu remisji definiowanej jako liczba PLT powyżej $150 \mathrm{G} / 1$ oraz ustąpienie objawów klinicznych. W wyniku zastosowanego leczenia uzyskano poprawę kliniczną u 7 pacjentów, natomiast brak spodziewanych efektów leczenia obserwowano u 2 chorych.

Plazmafereza znalazła zastosowanie również w leczeniu zespołu Lyella, zazwyczaj po uprzed- nim leczeniu farmakologicznym immunoglobuliną dożylną (IVIG, intravenous immunoglobulin) oraz kortykosteroidami. Zabieg stosuje się zarówno w przypadku progresji zmian chorobowych, jak i braku poprawy stanu klinicznego chorego. Uszkodzenie powierzchni skóry powoduje szybką utratę znacznych ilości wody i obniżenie ciepłoty ciała. Podczas wykonywania zabiegu aferezy należy zatem zadbać o utrzymanie prawidłowej temperatury ciała pacjenta oraz maksymalnie ograniczyć ryzyko zakażenia przez umieszczenie chorego $\mathrm{w}$ pomieszczeniu ogrzanym do $30-32^{\circ} \mathrm{C}$ ze stałym obiegiem powietrza oraz izolacją antybakteryjną. Taki zabieg stosowano $z$ pozytywnym skutkiem 
Tabela 3. Parametry zabiegu plazmaferezy zastosowane w wybranych jednostkach chorobowych

Table 3. Parameters of plasmapheresis in selected diseases

\begin{tabular}{|c|c|c|c|c|c|}
\hline Jednostka chorobowa & $\begin{array}{c}\text { Płyny } \\
\text { substytucyjne }\end{array}$ & $\begin{array}{l}\text { Pompa } \\
\text { napływu } \\
\text { [ml/min] }\end{array}$ & $\begin{array}{c}\text { TPV } \\
\text { wymiana }\end{array}$ & $\begin{array}{c}\text { Częstotliwość } \\
\text { aferez }\end{array}$ & $\begin{array}{l}\text { Średni czas } \\
\text { trwania [min]; } \\
\text { (przedział) }\end{array}$ \\
\hline TTP & $\begin{array}{l}\text { FFP inaktywowane } \\
\text { FFP bez AHG }\end{array}$ & $34-47$ & $1,5-2$ & $\begin{array}{l}1 \times / \text { dobę } \\
2 \times / \text { dobę }\end{array}$ & $\begin{array}{c}138 \\
(115-163)\end{array}$ \\
\hline HUS & $\begin{array}{c}\text { FFP } \\
\text { inaktywowane }\end{array}$ & $55-60$ & $1,4-0,9$ & $\begin{array}{l}1 \text { ×/dobę co- } \\
\text { dziennie }\end{array}$ & $\begin{array}{c}150 \\
(97-191)\end{array}$ \\
\hline PCM & $\begin{array}{c}\text { 5-proc. albumina } \\
\text { 20-proc. albumina } \\
0,9 \% \mathrm{NaCl}\end{array}$ & $50-70$ & $0,8-1$ & $\begin{array}{c}1 \times / \text { dobę } \\
2-3 \text { zabiegów }\end{array}$ & $\begin{array}{c}72 \\
(63-96)\end{array}$ \\
\hline Zespół Lyella & FFP inaktywowane & $35-45$ & $1,5-2$ & 2 ×/dobę & $\begin{array}{c}140 \\
(116-156)\end{array}$ \\
\hline $\begin{array}{l}\text { Autoimmunologiczne zapalenie } \\
\text { mózgu/zespół paranowotworowy }\end{array}$ & $\begin{array}{c}\text { 5-proc. albumina } \\
\text { 20-proc. albumina } \\
0,9 \% \mathrm{NaCl}\end{array}$ & $60-80$ & $0,8-1$ & $\begin{array}{l}1 \text { ×/dobę } \\
\text { Co 2. dzień } \\
5 \text { zabiegów }\end{array}$ & $\begin{array}{c}66 \\
(64-69)\end{array}$ \\
\hline
\end{tabular}

TPV (total plasma volume) - całkowita objętość osocza; TTP (thrombotic thrombocytopenic purpura) - zakrzepowa plamica małopłytkowa; FFP (fresh frozen plasma) inaktywowane - świeżo mrożone osocze po redukcji biologicznych czynników chorobotwórczych; AHG (anti-hemophylic globulin) - globulina antyhemofilowa; HUS (hemolytic uremic syndrome) - zespół hemolityczno-mocznicowy; PCM (plasma cell myeloma) - szpiczak plazmocytowy

u 48-letniego pacjenta (masa ciała $85 \mathrm{~kg}$, całkowita objętość osocza [TPV, total plasma volume] $4052 \mathrm{ml}$ ) po przeszczepieniu allogenicznych krwiotwórczych komórek z krwi obwodowej (allo-PBSC, allogenic peripheral blood stem cell transplantation) od dawcy niespokrewnionego (zgodność 10/10). Początkowo po zabiegu pacjenta po allo-PBSC wypisano do domu w dobrym stanie ogólnym, wyrównanym hematologicznie $z$ zaleceniem profilaktyki przeciwinfekcyjnej trimetoprimem $z$ sulfametoksazolem. Po 3 dobach pacjent wrócił do IHT w bardzo ciężkim stanie ogólnym, $z$ licznymi widocznymi na skórze pęcherzami, $z$ wysypką o charakterze rumienia wielopostaciowego $z$ objawem Nikolskiego, $z$ ostrą martwicą naskórka i błon śluzowych obejmującą ponad $30 \%$ powierzchni ciała. Po przeprowadzeniu 19 zabiegów aferezy zmiany skórne na twarzy i kończynach oraz $\mathrm{w}$ obrębie śluzówki przewodu pokarmowego i jamy ustnej uległy znacznej regresji. Parametry procedury przedstawiono w tabeli 4 .

\section{Rola pielęgniarki w procesie plazmaferezy}

Zabieg plazmaferezy zleca na piśmie lekarz, ale bezpośrednią kontrolę nad jego przebiegiem sprawuje pielęgniarka. Ze względu na bezpieczeństwo pacjenta za przeprowadzenie zabiegu powinna być odpowiedzialna osoba przeszkolona w zakresie wskazań i przeciwwskazań do zabiegu, objawów niepożądanych oraz wiedzy dotyczącej technik plazmaferezy. Głównym zadaniem pielęgniarki jest sprawne i bezpieczne przeprowadzenie zabie-
Tabela 4. Parametry zabiegu plazmaferezy zastosowanym w leczeniu zespołu Lyella

Table 4. Plasmapheresis parameters used in Lyell syndrome

\begin{tabular}{|l|c|}
\hline Parametr & Opis \\
\hline Połączenie naczyniowe & $\begin{array}{c}\text { Dwukanałowy cewnik } \\
\text { naczyniowy } 2 \times 14 \mathrm{G}\end{array}$ \\
\hline Częstotliwość aferez & $2 \times / 24 \mathrm{~h}$ \\
\hline Płyn substytucyjny & $\begin{array}{c}\text { FFP inaktywowane } \\
14-15 \mathrm{j} . / \text { /afereza }\end{array}$ \\
\hline Wymiana TPV & $0,9-1,0 \mathrm{TPV}$ \\
\hline Pompa napływu [ml/min] & $44(35-50)$ \\
\hline Czas trwania [min] & $140(116-156)$ \\
\hline
\end{tabular}

FFP (fresh frozen plasma) inaktywowane - świeżo mrożone osocze po redukcji biologicznych czynników chorobotwórczych; TPV (total plasma volume) - całkowita objętość osocza

gu plazmaferezy zgodnie $z$ zaleceniami lekarza. Podczas zabiegu pielęgniarka ściśle współpracuje z lekarzem, zgłaszając mu swoje obserwacje odnośnie do ewentualnie występujących objawów niepożądanych. Ponadto prowadzi dokładną dokumentację (indywidualną i zbiorową) obejmującą dane pacjenta i przebieg procedury oraz rejestr płynów i zestawów używanych podczas zabiegu. Dokumentacja zabiegu musi uwzględniać rodzaj i objętość płynów zastępczych, jak również objętość pobranego osocza.

Przed przystąpieniem do zabiegu plazmaferezy niezwykle istotne znaczenie ma sprawdzenie dostępu naczyniowego. Trudności spowodowane słabym napływem krwi uniemożliwią sprawne i skuteczne przeprowadzenie tej procedury. Ważne 
jest także nawiązanie kontaktu $\mathrm{z}$ pacjentem w celu zmniejszenia napięcia i lęku związanego $z$ samym zabiegiem oraz wyjaśnienia pacjentowi, dlaczego przeprowadzenie zabiegu jest konieczne. Zakwalifikowany do zabiegu chory powinien otrzymać pełną informację dotyczącą działan pielęgniarskich przed zabiegiem, w trakcie zabiegu oraz po jego zakończeniu. Należy zapewnić pacjenta, że w czasie zabiegu będzie miał zapewnioną opiekę wykwalifikowanej pielęgniarki. Swoim zachowaniem pielęgniarka powinna wzbudzać zaufanie chorego.

\section{Przygotowanie do zabiegu}

Przygotowanie do zabiegu plazmaferezy obejmuje odpowiednie przygotowanie zarówno sprzętu, jak i samego pacjenta. Separator (w przypadku aferezy automatycznej) lub wagomieszarkę (w przypadku plazmaferezy manualnej) należy umieścić tak, aby jednocześnie kontrolować pacjenta i sprzęt medyczny. Należy używać oryginalnych, jednorazowych, jałowych zestawów zalecanych przez producenta aparatury. Przed zabiegiem należy każdorazowo wykonać pomiar ciśnienia tętniczego i tętna pacjenta. Jeśli procedura obejmuje usunięcie osocza pacjenta i uzupełnienie FFP, to pielęgniarka jest za każdym razem zobowiązana do kontroli zgodności składnika krwi przeznaczonego do przetoczenia. Kontrola ta polega na:

- porównaniu grupy krwi na etykiecie składnika z grupą krwi pacjenta w układzie ABO;

- $\quad$ sprawdzeniu daty ważności składnika;

- poddaniu ocenie wizualnej rozmrożonego osocza i szczelności pojemników.

W ocenie wizualnej rozmrożone osocze nie powinno zawierać przebarwień, skrzepów ani nierozpuszczonych strętów. Nie wolno przetaczać osocza z przeciekających lub uszkodzonych pojemników. Przed przetoczeniem i po jego zakończeniu należy dokonać pomiaru i rejestracji ciepłoty ciała oraz ciśnienia tętniczego pacjenta. Jest to postępowanie zgodne $z$ rozporządzeniem ministra $z$ drowia z 16 października 2017 roku dotyczącym organizacji leczenia krwią w zakładach opieki zdrowotnej.

\section{Przygotowanie pacjenta}

do zabiegu plazmaferezy

W ramach przygotowania pacjenta do zabiegu:

- zaleca się, aby chory się wypróżnił, był po spożyciu lekkiego posiłku (drażniące działanie antykoagulantu jest wtedy mniejsze). Nie zaleca się palenia tytoniu, ponieważ nikotyna powoduje obkurczanie naczyń krwionośnych. Należy uprzedzić chorego o możliwości wystąpienia objawów niepożądanych oraz o ko- nieczności zgłaszania pielęgniarce każdego niepokojącego doznania;

- należy odpowiednio ułożyć ramiona pacjenta na miękkich podkładkach ze względu na długotrwałe unieruchomienie podczas zabiegu (dotyczy wykorzystania igieł do połączenia naczyniowego). Podczas procedury można ostrożnie zmieniać ułożenie ramion, kontrolując, czy zmiana ta nie pogarsza położenia igły w naczyniu.

Istotnym elementem zabiegu aferezy jest aseptyczne połączenie łożyska naczyniowego, co obniża ryzyko/niebezpieczeństwo zakażenia i/lub zapalenia żyły. Należy pamiętać, że intensywne zabiegi plazmaferezy powodują obniżenie odporności u pacjentów, co szczególnie sprzyja podatności na zakażenia.

\section{Rola pielęgniarki podczas} zabiegu plazmaferezy

Stan pacjenta poddawanego zabiegowi terapeutycznej wymiany osocza jest zazwyczaj wyjściowo ciężki i wymaga znacznej ingerencji w układ homeostazy. $Z$ tego względu konieczne są stała obserwacja jego parametrów życiowych (ciśnienia tętniczego, tętna) oraz miejsc połączenia $z$ łożyskiem naczyniowym (możliwość wystąpienia mechanicznego uszkodzenia naczyń i podskórnego wynaczynienia krwi), obserwacja pod kątem wystąpienia objawów niepożądanych związanych $z$ indukowanym podawaniem antykoagulantu (hipokalcemia i hipomagnezemia), podjęcie odpowiednich czynności oraz oceny prawidłowego przebiegu procedury (stała kontrola aparatu, przepływu płynów zwrotnych i antykoagulantu, ciaggego przepływu krwi podczas pobierania metodą konwencjonalną, temperatury przetaczanych płynów). Wszystkie te czynności wchodzą w zakres obowiązków i odpowiedzialności wykwalifikowanej pielęgniarki.

Zabiegi plazmaferezy uważa się za stosunkowo bezpieczne, jednak zawsze należy się liczyć $z$ ewentualnością wystąpienia objawów niepożądanych, które mogą stanowić zapowiedź poważnych komplikacji. Najpoważniejsze powikłania wiążą się $z$ podażą obcych białek. Podczas zabiegu mogą wystąpić objawy poprzetoczeniowe w postaci nagłego obniżenia ciśnienia tętniczego, świądu skóry, rumienia lub wysypki w reakcji na przetaczane płyny substytucyjne, głównie FFP pochodzące od różnych dawców. W takiej sytuacja pielęgniarka musi natychmiast przerwać zabieg, ocenić sytuację i powiadomić lekarza nadzorującego zabieg.

Zabieg plazmaferezy wiąże się ze znacznym obciążeniem układu krążenia, co w połączeniu 
Z wyjściowo/pierwotnie niskimi wartościami ciśnienia tętniczego, niewydolnością krążenia lub niedokrwistością może powodować - zwłaszcza we wczesnej fazie zabiegu — groźne spadki ciśnienia tętniczego $z$ pogorszeniem perfuzji krwi przez naczynia obwodowe, spadkiem ukrwienia i odżywienia tkanek. Zarówno w trakcie zabiegu plazmaferezy, jak i bezpośrednio po jego zakończeniu mogą u pacjenta wystąpić zaburzenia oddechowe, dlatego należy chorego pod tym kątem obserwować. W różnicowaniu tych zaburzeń należy uwzględnić:

- reakcje alergiczne z pokrzywką i skurczem oskrzeli (dotyczą przetoczeń osocza);

- masywny zator płucny na skutek podania niedostatecznej ilości antykoagulantu;

- obrzęk płuc na tle przeciążenia płynami lub niewydolności krążenia;

- ostry obrzęk na tle uszkodzenia naczyń włosowatych pęcherzyków płucnych (reakcja immunologiczna).

W przypadku wystąpienia tego typu zaburzeń pielęgniarka powinna natychmiast przerwać procedurę i skontaktować się $z$ lekarzem nadzorującym zabieg. Brak odpowiedniej kontroli ilości usuwanego osocza i płynów zastępczych ze strony pielęgniarki doprowadzić może do wahań hemodynamicznych, objawiających się wzrostem i spadkiem ciśnienia tętniczego, bólami głowy, pogorszeniem wydolności krążenia i zaburzeniami rytmu serca. Aby do tego nie dopuścić pielęgniarka kontroluje wszystkie parametry procedury, szczególnie w zakresie suplementacji.

Jeśli procedura prowadzona jest w niskiej temperaturze u pacjenta mogą wystąpić dreszcze spowodowane ochłodzeniem płynów (powierzchnia przewodów separatora wystawiona jest na działanie niskiej temperatury otoczenia). Aby do tego nie dopuścić pielęgniarka kontroluje temperaturę otoczenia a $\mathrm{w}$ razie potrzeby okrywa pacjenta kocem. Przetaczanie zwrotne zimnych płynów zawierających cytrynian przez cewnik wprowadzony do dużego naczynia może powodować zaburzenia rytmu serca wywołane bezpośrednim kontaktem $z$ węzłem zatokowym. $Z$ tego względu należy przetaczać płyny wyłącznie o pokojowej temperaturze.

Dla prawidłowego przebiegu procedury niezwykle istotne znaczenie ma współpraca pielęgniarki z pacjentem. Stała obecność pielęgniarki podczas zabiegu, jej opanowanie i spokój pomagają choremu pozbyć się lęku i zapewniają mu poczucie bezpieczeństwa.
Postępowanie $\mathrm{z}$ pacjentem po zabiegu plazmaferezy

Po osiągnięciu wartości docelowych należy usunąc kolejno wkłucia, zaopatrując miejsca wkłucia jałowym opatrunkiem uciskowym. Jeżeli do zabiegu wykorzystano cewnik naczyniowy (w połączeniu żylno-żylnym) należy po odłączeniu zestawu przepłukać oba kanały 0,9-procentowym $\mathrm{NaCl}$ i zaopatrzyć jałowymi koreczkami. W przypadku głębokich wkłuć tętniczo-żylnych należy kanał tętniczy (zgodnie $z$ zaleceniami lekarza) wypełnić heparyną w ilości zależnej od długości kanału lub przepłukać roztworem soli fizjologicznej $z$ heparyną. Wszystkie czynności należy wykonywać zgodnie $z$ zasadami aseptyki. Pielęgniarka, która ma kontakt $z$ takimi pacjentami musi być dobrze przygotowana i przeszkolona w zakresie obchodzenia się $z$ cewnikiem naczyniowym.

Po zakończeniu zabiegu plazmaferezy do zadań pielęgniarki należy kontrola i ocena stanu chorego. W tym celu pielęgniarka powinna wykonać pomiar ciśnienia tętniczego, tętna oraz temperatury, jeśli choremu przetaczano osocze.

Rola pielęgniarki we współczesnej transfuzjologii opiera się zarówno na zdobytej wiedzy medycznej i sprawnościach technicznych, ale również na doświadczeniu i poczuciu odpowiedzialności za wykonywaną pracę. Ogromne znaczenie dla holistycznej opieki nad pacjentem leczonym zabiegami plazmaferezy jest jakość wykonanej procedury. Pielęgniarki, które sprawują nadzór nad przebiegiem takiej procedury stanowią ważne ogniwo w procesie leczenia, a od ich poziomu profesjonalizmu zależy skuteczność terapeutyczna zabiegu i bezpieczeństwo pacjenta.

\section{Podsumowanie}

Zabiegi plazmaferezy są coraz bardziej powszechne i znajdują zastosowanie w leczeniu coraz większej liczby jednostek chorobowych. Stosowanie technik pozaustrojowego wspomagania organizmu umożliwia zarówno niesienie doraźnej pomocy (np. przy zatruciach), jak i podtrzymywanie funkcji życiowych organizmu w dłuższym okresie czasu (np. choroby autoimmunizacyjne, dyskrazja komórek plazmatycznych). Do niedawna plazmafereza była stosowana w ostateczności, w stanach zagrożenia życia. Obecnie coraz częściej sięga się po techniki pozaustrojowego oczyszczania krwi w celu wspomagania klasycznych metod leczenia.

Wraz z rozwojem nowych technik i materiałów liczba stosowanych zabiegów plazmaferezy gwałtownie wzrosła. Wysoki poziom techniczny 
separatorów zapewnia bezpieczeństwo pacjentom, jak również skuteczność terapeutyczną. Barierę ograniczającą liczbę zabiegów stanowi jednak znaczny koszt procedury jak również powikłania po zabiegu, które chociaż sporadycznie, ale występują.

Każda $z$ obecnie stosowanych technik plazmaferezy ma zarówno zalety, jak i wady. Wymiana osocza, choć efektywna, jest nieselektywna, a ze względu na konieczność podawania płynów zastępczych także ryzykowna i kosztowna. Płyny zastępcze zawierające albuminy są drogie, nie zawierają immunoglobulin, czynników krzepnięcia, ani czynników układu dopełniacza. Jeśli są one stosowane jako jedyny płyn uzupełniający mogą powodować skazę krwotoczną, zaburzenia elektrolitowe i spadek odporności na zakażenia (ubytek immunoglobulin G).

W doniesieniach $z$ innych ośrodków nie stwierdzono zasadniczej różnicy w skuteczności między metodą wirówkową, a filtracyjną. Jednak w metodzie filtracyjnej liczy się szybkość i wyższa aseptyka wykonanego zabiegu [6, 7].

Pacjenci leczeni zabiegami plazmaferezy są szczególnie narażeni na ryzyko infekcji związanej $z$ obniżeniem odpowiedzi humoralnej, której przyczyną jest usuwanie wraz $z$ osoczem immunoglobulin i frakcji dopełniacza C3, C4. Podczas plazmaferezy wraz $z$ osoczem $z$ krążenia mogą zostać usunięte czynniki związane $z$ odpowiedzią immunologiczną, takie jak: autoprzeciwciała, alloprzeciwciała, immunoglobuliny, kompleksy immunologiczne, białka monoklonalne i cytokiny. Pomimo utraty wymienionych czynników związanych $z$ odpowiedzią immunologiczną, obserwuje się szybką ich regenerację, co dodatkowo potwierdza, że zabieg plazmaferezy jest bezpieczny. Odległym następstwem u osób, które są często poddawane są zabiegom plazmaferezy, może być utrzymujący się przez kilka miesięcy spadek liczby limfocytów $\mathrm{T}$ i B. Jednak poważne konsekwencje wynikające $z$ tych zmian nie są znane [7].

Chorzy zakwalifikowani do zabiegu plazmaferezy leczniczej często przechodzą przedtem intensywne leczenie połączone $z$ wielokrotnym nakłuwaniem żył, co skutkuje znacznym utrudnieniem dostępu naczyniowego i stwarza konieczność założenia cewnika naczyniowego do żyły głębokiej (dwukanałowego w przypadku separatora o przepływie ciagłym). Niezwykle istotne znaczenie ma współpraca pomiędzy zespołem wykonującym zabieg, a oddziałem macierzystym chorego w ce- lu utrzymania drożnego dostępu naczyniowego (prawidłowa pielęgnacja dostępu naczyniowego). Umożliwia to przeprowadzenie serii zabiegów bez potrzeby nakłuwania żył pacjenta, a to przyczynia się do obniżenia poziomu stresu i bólu u chorego oraz wpływa na poprawę jego samopoczucia.

Udział w zabiegach plazmaferezy leczniczej stanowi dla pielęgniarki wyzwanie, ale jednocześnie stwarza jej możliwość doskonalenia umiejętności zawodowych i pogłębiania wiedzy w zakresie obiecujących, a niestosowanych jeszcze powszechnie metod leczenia.

\section{Piśmiennictwo}

1. Wołyniec W, Urbaniak M. Plazmafereza lecznicza. Via Medica, Gdańsk 2009.

2. Wiśniewska B. Plazmafereza lecznicza w praktyce pielęgniarskiej. Praca licencjacka. Akademia Medyczna w Warszawie, Wydział Nauki o Zdrowiu, Warszawa 2007.

3. Antoszewski Z, Skalski J. Hemotransfuzja, autohemotransfuzja i hemodylucja sterowana w zastosowaniu klinicznym. „Śląsk” Wydawnictwo Naukowe, Katowice 2000.

4. Jakóbisiak M, Lasek M, Stokłosa T. (red.). Immunologia — podręcznik dla studentów. Wydawnictwo Naukowe PWN, Warszawa 2001.

5. Nałęcz M. Sztuczne narządy. Akademicka Oficyna Wydawnicza Exit, Warszawa 2001.

6. Seczyńska B. Plazmafereza możliwe powikłania i ich zapobieganie. Przegl Lek. 2011: 637-640.

7. Rosiek A. Hemafereza lecznicza. J Transf Med. 2010; 3: 92-98.

8. Ferenc T, Łukasiewicz B, Ciećwierz J, et al. Zatrucia muchomorem sromotnikowym (amanita phalloides). Medycyna Pracy. 2009; 60(5): 415-426.

9. Smycz M, Mielczarek-Palacz A, Kondera-Anasz Z, et al. Zastosowanie plazmaferezy w terapii oraz w preparatyce krwi. Ann Acad Med Siles. 2012; 66(1): 67-72.

10. Schwartz J, Padmanabhan A, Aqui N, et al. Guidelines on the use of therapeutic apheresis in clinical practice-evidence-based approach from the Writing Committee of the American Society for Apheresis: the Seventh Special Issue. J Clin Apher. 2016; 31(3): 149-162, doi: 10.1002/jca.21470, indexed in Pubmed: 27322218.

11. Guyatt G, Gutterman D, Baumann MH, et al. Grading strength of recommendations and quality of evidence in clinical guidelines: report from an American College of Chest Physicians Task Force. Chest. 2006; 129(1): 174-181, doi: 10.1378/chest.129.1.174, indexed in Pubmed: 16424429

12. Korsak J, Łętowska M. Transfuzjologia kliniczna. Alfa-Medica Press, Bielsko-Biała 2009: 261-276.

13. Mintz D. Leczenie krwią, zasady postępowania klinicznego. Wydawca wydania polskiego - Sekcja Transfuzjologiczna Polskiego Towarzystwa Hematologów i Transfuzjologów, Warszawa 2001.

14. Dmoszyńska A, Robak T. Podstawy hematologii. Wydawnictwo Czelej, Lublin 2003.

15. Górska-Kosicka M, Windyga J. Praktyczne aspekty diagnostyki i leczenia zakrzepowej plamicy małopłytkowej. Hematologia. 2017; 8(1): 12-19, doi: 10.5603/hem.2017.0002. 